\title{
HARMONY IN RELIGIOUS AND CULTURAL DIVERSITY, CASE STUDY OF SUNGAI PENUH CITY SOCIETY
}

\author{
Masnur Alam \\ Institut Agama Islam Negeri Kerinci \\ masnur.alam@yahoo.com
}

\begin{abstract}
This article was motivated by recent development in Indonesian society whose religious and cultural diversity has raised a lot of racial issues that lead to tension and suspicion among communities in the Sungai Penuh, Kerinci Regency, Jambi province on Sumatra Island. The impact could potentially trigger conflict, damage, inconvenience and could further threaten national unity and national integration. This article gives an overview that religion (Islam) has a very positive philosophy that in fact humans are created in religious and cultural diversity. Diversity is the law of God, something that is commonplace, rule of time, a must, and divine grace to be grateful for, a form generosity from God to humans as the strength, the reason to do good. The government together with the community has been able to build harmony in diversity, creating peace, moderation, compassion, love of peace, tolerance, avoiding conflict, so as to build the country as planned. In socializing the attitude of harmony, the government can do it through formal and non-formal ways, eventually people can implement it in their daily lives. Thus, the government and the public can establish harmony in diversity, creating peace, security, order, justice, tranquility, comfort as well as brotherhood and compassion. The government together with the community can come together, foster mutual cooperation to achieve the goals the country's development. This paper also recommends to religious communities with diverse cultures to always build harmony as one of the solutions in creating peace and free from conflict, as well as serving as capital to build the country, nation, state and religion.
\end{abstract}

Keywords: harmony, religion, culture, Sungai Penuh.

\section{INTRODUCTION}

Indonesia when seen from the number of people is a very diverse country with a population of over 250 million, inhabited by 700 ethnic groups speaking some 500 languages, home to thousands of cultural traditions, 6 "officlal" religions and hundreds of forms of mysticism and local beliefs. With such diversity, or heterogeneity of society, it will be very easy for radical groups to grow into 
violence and extremity. Thus it would be prone to conflict, such as enmity, strife, animosity and disharmony, discrimination against different groups, particularly against minorities. Conflicts in Indonesia can be seen from two factors, namely internal and external. Internal factors include the fact that this country is facing the emergence of separatism and conflict or unrest tinted with racial intolerance, fundamentalism, extreme groups who believe that they have the absolute truth and that their values should be applied. For example, the emergence of mass organization called Gerakan Fajar Nusantara (Gafatar) which was suspected of affiliation with the organization of the Islamic State of Indonesia (NII) which is indicated as heretical, has a progressive movement, with advanced thought. It is very disturbing as a lot of missing people have been found as a follower of the Gafatar. Likewise, the emergence of the East Indonesia Mujahidin (MIT) led Santoso, a militant group that was not in accordance with the teachings of religion and humanity.

In addition, the external factors are also affecting the situation in this country, namely the various movements to take root in the Middle East or elsewhere that wish to establish a Caliphate, a single universal Islamic political entity, either through "peace" or "radical" ways or employing terrorist attacks which are increasing open. Further, the emergence of militant Islamic State of Iraq and Syria (ISIS) whose henchmen have spread to many countries in the world including Indonesia. The ISIS claimed to be the group responsible for the 'concert' (terror) in the capital of Indonesia in Jakarta on January 14, 2016. On July 5, 2016, Muslims who were expecting Eid were shocked by terror attacks on the police headquarters in Surakarta, Central Java and Indonesian citizens held hostage by the Abu Sayyaf of the Philippines. Global issues that catch the international attention are terrorist attacks, radical movements with religion as the culprit. Yet every religion and culture does not have the term radicalism and terrorism. So with such treatment, the atmosphere of Indonesia which is known so far as a very safe and conducive place, once there was a terror bomb, it turned into a chaotic, uncontrolled area. This atmosphere if not anticipated, will continue to occur endlessly, and always haunt us all the time. Casram (2016) argues that Indonesians are in the possition of supporting the efforts of building better tolerance in a pluralistic society.

In addition, it is also common knowledge that there are people who are exclusive, extreme, intolerant of differences. Exclusive attitude refers to the belief in the absolute truth of religion, denying the truth of other religions, eventually growing the seeds of extremity, seeing things as black and white, assuming they are right and others are wrong. One can do something outrageous, taking actions that lead to violence against other groups. Furthermore, extreme 
attitude can lead to the inability to be tolerant, which arises because we cannot or do not want to accept and respect differences. Religious and cultural intolerance can lead to strained relations between people or communities, faiths and different cultures. Thus the atmosphere will not be harmonious, because they do not appreciate and respect diversity. With these conditions, we will not be able to build the country well, because we've been busy with the split, even if this condition continues massively, this Republic will not be secure anymore. This situation should be avoided, because it gives rise to tension, friction and even massive conflict. All humans wish for harmonious and peaceful life and no one wants conflict and violence. Once conflict and violence get in the way of building harmony, peace becomes fragile and not easily reestablished. Moreover, mutual trust and respect of the beliefs of others will fade. So, it is necessary to endeavor to establish peace. Such situation, if not anticipated, could threaten national integration. Zaenuddin Hudi Prasojo (2016) gives an example of the situation in West Kalimantan in which three influencial ethnic groups live tother; the Tidayu as from Tionghua (the Chinese Indonesian, Dayak and Malay). He further explains that there has been a potential of politicing the ethno-religious identity in the region including the three groups but they have come up with appropriate anticipation.

The phenomena described above reflect an idea that radicalism in Indonesia has spread to every line, religion, culture, mass organization, both in rural and urban areas. The attitude of radicalism, mutual mistrust, prejudice, exclusiveness and extremism should be stopped or minimized in order not to spread, to maintain the unity. We must be able to create a pluralistic Indonesia as divine grace to be grateful, as well as the strength, the nation's capital for development that must be managed to face the emerging challenges in the era of globalization. One of the efforts that must be done is to build harmony in religious and cultural diversity so that we can build the country with a variety of achievements and develop a sense of moderation, tolerance and peace, especially for cities or areas that have a high level of diversity in terms of culture and religion.

\section{SUNGAI PENUH AS A HETEROGENEOUS CITY}

As is found in the research data that Sungai Penuh City of Jambi Province has a heterogeneous community with various characteristics and diversity of religions and cultures, tribes, traditions, customs, and languages. Such conditions can only last if the community maintains harmony and appreciate the diversity of religions and cultures so that the creation of peace and mutual respect, respect for the diversity, 
and free from conflicts and disturbances can be sustainable. In the spirit of mutual and beneficial cooperation, regardless of differences of religions, culture, ethnicity and languages, they can develop the country, make achievement in the era of globalization. This is a typical local wisdom that deserves to be imitated, emulated and guided.

This paper is written from the results of research using a qualitative approach. The collection of primary data was done through interviews with key informants to determine the roles, namely representatives of regional work units (SKPD), Chairman of the Indonesian Ulema Council (MUI), Chairman of the Forum for Religious Harmony (FKUB), Chairman of the National Assimilation Forum, Chairman of Indigenous People. Interviews were conducted to determine how the government socialized the attitude of harmony in society. The observations were made to reveal the reality, grasp and understand the phenomenon and the real condition of the actual, observed the research object, the communication process of government and members of the community in terms of socialization of the attitudes in building harmony in religious and cultural diversity, as well as the results of development which have been achieved by the government of Sungai Penuh City. Study of documents was made on the literature relevant to the education of harmony, religion and culture and on Warta Kota Magazine of Sungai Penuh City.

From the results of research conducted by the author, it can be revealed that the Sungai Penuh is a city that has a very high diversity. Cultural diversity occupies the highest rank, followed by ethnic diversity and diversity of belief or religion. Local religion practiced by people who assimilated with Islam, Christianity, Hinduism and Buddhism which shapes Sungai Penuh to be a place with with a high diversity of beliefs. Hence, the public also has high dynamics, both in relation to everyday life and in the context of the people and the nation. The role of governments and civil society organizations becomes an important part of community life in the dynamics of Sungai Penuh City.

\section{PHILOSOPHY OF HARMONY IN DIVERSITY}

According to the English Indonesian Dictionary, the word 'harmony' is translated as: keselarasan, keserasian, kecocokan, kesesuaian, kerukunan. H.A.W. Wijaya ${ }^{2}$ stated that harmony actually has become a priority for national

${ }^{1}$ John M.Echols dan Hassan Shadily, Kamus Inggris Indonesia, (Jakarta. Gramedia, 1984), p, .290

${ }^{2}$ H.A.W. Widjaja, Pedoman Pelaksanaan Pendidikan Pancasila Pada Perguruan 
development objectives, namely the development in the field of religion and belief in God Almighty which is reflected in an atmosphere of harmonious life, as well as the strength of national unity in harmony with appreciation and practice of Pancasila.

The creation of a harmonious life is characterized by the dominance of the spirit of friendship, and conflict is characterized by the dominance of feelings of hostility and enmity. So to manage harmony in life of the nation can be done through familiarizing friendship, and appreciate the surrounding communities, national society and the global community. Committed to building a harmonious life is to recognize the diversity of religion and culture and appreciate and respect each other's differences gracefully. Thus only through creating peace, national integration, national unity can the realization of a prosperous, safe, and peaceful country be achieved.

In order for people to live in harmony with others, they should not limit their love for themselves and be selfish. They also should balance such affection to others, work together or provide assistance to each other, like sharing with each other, compassion, love others as they loves themselves, especially those who need help. Thus they should be able to balance between their love for themselves with their love to others. According to M. Jusuf Kalla, ${ }^{3}$ the Vice president of Indonesia, basically, the realization of brotherly love, unity, happiness, and cooperation is the purpose of our life together as a religious community.

The harmonious atmosphere is supposed to be created in a life of diversity of religions and cultures, ethnic groups, because man is created in diversity. God has made humans in various nations (Q.S. Al- An'am [6]: 42), or some peoples (Q.S. Al-An-fal [8]: 53). God also created various tribes and nations "O mankind, indeed We have created you from male and female and made you peoples and tribes that you may know one another." (Surah Al-Hujurat [49] : 13). This verse explains that we are created God not in uniformity, but in diversity and differences. Diversity is the law that cannot be denied. As written by M. Nur Kholis Setiawan ${ }^{4}$, diversity is not something negative, but a positive situation that contributes optimally. Dede Rosyada et al. ${ }^{5}$ also argued that if there are efforts and policies of cultural uniformity by the state, it is a violation of the human rights, as it leads to the elimination of multiculturalism of the

Tinggi,(Jakarta: Raja Grafindo Persada, 2002), $2^{\text {nd }}$ edition p. 284

${ }^{3}$ M. Jusuf kall, Kompas, Monday, 23 May 2016, p. 1

${ }^{4}$ M. Nur Kholis Setiawan, Pribumisasi Al-Quran: Tafsir Berwawasan Keindonesiaan,(Yokyakarta: Kaukaba,2012), p. 34

${ }^{5}$ Dede Rosyada dkk. Demokrasi dan Hak Asasi Manusia \& Masyarakat Madani, (Jakarta ICCE UIN Syarif Hidayatullah, 2003), p. 206 
identity of the citizens and the wealth of a nation.

Mulciculturalism is a synonym of pluralism and diversity. Pluralism of religions and cultures is a necessity for the salvation of mankind. Pluralist attitude, as put forward by Muhammad $\mathrm{Ali}^{6}{ }^{6}$ is the attitude of believing the truth, trying to understand, appreciate, and accept the possibility of the truth of the others, and furthermore, being ready to cooperate actively in the midst of differences. At present and in the future, we cannot avoid pruralism, both religious and cultural. In religious pluralism, Komarudin Hidayat ${ }^{7}$ said the recognition is to provide place for other religions as a truth recognized by its respective followers. Similarly, Nurcholish Madjid ${ }^{8}$ stated that recognition of other religions is a form of implicit Muslim faith, even though he still believes that their religion is the best and right, yet at the same time, they have the tolerance and friendship with people of other faiths. So under these conditions, tolerance should be encouraged in order to create peace in the society and the nation. With the creation of peace, it will create harmony in the diversity of religions and cultures.

Nur Syam said ${ }^{9}$ that plurality is defined as a colorful, heterogeneous life, and acknowledging other people who are different, but can live in a single locus and habitus with social and cultural dynamics, not something that is contrary to the Sunnah of Allah which is indeed necessary to establish the pluralism. The Words of God says "And if it were not for Allah checking [some] people by means of others, the earth would have been corrupted, but Allah is full of bounty to the worlds" (Q.S. Al-Baqarah [2]: 251). In understanding this verse, Budhi Munawar Rahman ${ }^{10}$ said an affirmation that God created supervision mechanisms and balance between humans to maintain the integrity of the earth, and is a manifestation of God's abundant mercy to mankind. Pluralism must be interpreted as a logical consequence of the Divine justice. Religion should participate to reconcile conflicting realities to achieve harmony.

According to Burhanuddin Daya, ${ }^{11}$ religion on the one hand is a force for

\footnotetext{
${ }^{6}$ Muhammad Ali, Teologi Pluralis-Multikultural: Menghargai Kemajemukan Menjalin Kebersamaan,( Jakarta:Penerbit Buku Kompas, 2003), p.xii

${ }^{7}$ Komarudin Hidayat \& Muhammad Wahyudin Nafis, Agama Masa Depan, Persfektif Filsafat Perinial, (Jakarta Paramadina, 1995), p. 71

${ }^{8}$ Nurcholis Madjid, Foreword: Grose \& Hubbard, p. Xix.

${ }^{9}$ Nur Syam, Mazhab-Mazhab Antropologi, (Yokyakarta: LkiS, 2011),p. 203

${ }^{10}$ Budhi Munawar Rahman, Islam dan Pluralis Kesetaraan Kaum Beriman, (Jakarta: Paramadina, 2001), p.31

${ }^{11}$ Burhanuddin Daya \& Herman L. Beck (Redaktur), Ilmu Perbandingan Agama di Indonesia dan Belanda, (Jakarta: INIS, 1992), p. 168
} 
movements of humanity, justice and peace, but on the other hand can lead to religious discord and even violence. In this regard, Nurchalis Madjid ${ }^{12}$ revealed that the development of religious life and diversity now generally tends to look at the differences rather than the similarities, it is true and very commendable, as long as it does not cause social destruction. In the face of these conditions, Farooq Kathwari ${ }^{13}$ President Director of Ethan Allen Furniture said, in the face of diversity "Let's share diversity and tolerance, and look at freedom of religion and culture as important. Thus the condition could be more neutral and safer.

Human differences of languages and skin color must be accepted as a positive reality (Q.S. Ar-Rum [30]: 22). Differences should not be "reprimanded" in life, and should be used as a base of strength and good deeds. Islam considers that all or part of the human race are the same as the word of the Prophet. "All men are the same as the teeth of the comb, an Arab is no better that on a Ajam (non-Arab) except for his piety". Human community and cultural diversity are no longer in the boundaries, but everything is widespread, broad and global.

Thus it can be understood that the religious and cultural diversity is the law of God, la of the times, something that is commonplace, but how we strive to be a people or nation capable of creating a sense of peace and prosperity in the midst of the social life, instead of resentment and hatred of one another, or hostility due to differences in religious beliefs. According Komaruddin Hidayat ${ }^{14}$ attitude of Muslims should be able to tolerate differences and reward appropriately to everyone, not only confirms their own beliefs and denying other people's creed. Likewise Johan Efendi ${ }^{15}$ revealed that we should be able to get out of the storm of narrow religiousness, into the diversity of the a more mature future.

In the same way, the chairman of the National Movement of Advanced Indonesia (PIM), Din Syamsuddin, ${ }^{16}$ in a speech said "Indonesia's pluralism is a divine blessing which we should be grateful for. Pluralism should be a force for the betterment of the nation and not a weakness that triggered the split". The most important thing in such diversity is the creation of peace between them. Islam is a religion that loves peace and people are inclined to peace. "And if they are incline to peace, then incline to it and put thy belief in Allah"

${ }^{12}$ Nurchalis Madjid, Tradisi Islam Peran dan fungsinya dalam Pembangunan di Indonesia, (Jakarta: Paramadina, 1997), p. 70

${ }^{13}$ Farooq Kathwari, Republika, Saturday, 2 May 2016, p. 12

${ }^{14}$ Komaruddin Hidayat dan Ahmad Gaus AF (editor), Islam Negara \& Civil Sosiety, Gerakan dan Pemikiran Islam Kontemporer, ( Jakarta: Paramedina, 2005), p. 502

${ }^{15}$ Yusnar Yusuf, (Pengantar Djohan Efendi), Prasangka Ber-agama, (Jakarta:Penamadani, 2004), p.xxiv

${ }^{16}$ Din Syamsuddin, Kompas, Monday, 23 May 2016, p 5, column 1 
(Q.S. Al Anfal [8]: 62). According Komari A. Ahmadi, Prophet Muhammad ${ }^{17}$ never refused to live in peace, always accepted invitations to peace, although was always betrayed by the enemy.

According to Tata M. Taufik ${ }^{18}$, greeting "assalamualaikum" in addition to containing a prayer for peace for anyone to find, also means that it is able to bring the spirit of peace, "to see you with a spirit of peace" or "I have come to bring peace to you". Thus it can be understood that it is not simply word of greeting, but further it can give birth to peace in the midst of society. In terms of communication or interaction between Muslims and non-Muslims, we should be able to maintain the character of Muslims to become sympathetic, should not be a provocateur that could result in a conflict, but should be the one to spread peace with other human beings. In accordance with the mission of spreading the Islamic teachings of peace and well-being, the Islamic concept of social interaction is more oriented towards achieving "peace" and "harmony" between human beings, regardless of religious background or race. Peace can be understood as a harmonious state of physical, mental, spiritual, and social, at peace with God through obedience, and peace with our fellow human beings to avoid intrusion. Islam requires its followers to seek peace in all areas of life. Islam is very committed to freedom, justice, equality, and peace in the world.

As good citizens, we should be compassionate to one another, and can show consideration and concern for others. According to Abdullah Nashih Ulwan, ${ }^{19}$ compassion is a softness in the heart, smooth feelings in the conscience, and an excellent sense which leads to gentle treatment of others, feeling of caring, compassion toward them and the effort to eliminate grief and suffering of others. The affection is not limited to the brothers who are believers, but even abundant to all humanity. Thus creating a harmony that is a reflection of mutual relations characterized by mutual acceptance, mutual respect, solidarity, and tolerance that is able to accept that the differences with what has become self-confidence.

Tolerance, cited from the Dictionary of al-Munawir ${ }^{20}$ is termed with

${ }^{17}$ Komari, A. Ahmadi, Perang dan Damai dalam Islam, (Bandung: Pustaka Setia, 1995), p. 274

${ }^{18}$ M. Tata Taufik, Langkah-langkah Menuju Surga, Gema MUI Edisi XVI, Jum’at 26 Rabiul Tsani 1427 P/23 June 2006.

${ }^{19}$ Abdulllah Nashih Ulwan,(Terj.Saifullah Kamaile), Pedoman Pendidikan Anak daIam Islam,( Semarang, CV. Asysyifa', 1993), p. 400

${ }^{20}$ Ahmad Warson Munawir,Kamus al-Munawir, (Yokyakarta: PP Krafyak, 1994),p.702 
the word tasamuh meaning graceful gesture. A. Zaki Badawi ${ }^{21}$ said tasamuh (tolerance) is the willingness to accept a wide range of views and diversity, tolerance, mutual respect and mutual respect. In Big Indonesian Dictionary ${ }^{22}$ means tolerating. Yayah khisbiyah ${ }^{23}$ explained, tolerance is build better social relationships. Thus, it will give birth to harmony in the nationhood and statehood,

\section{BUILDING HARMONY IN DIVERSITY OF RELIGION AND CULTURE}

In building harmony, Sungai Penuh Government is making use of the structural model of top-down to make policies in achieving harmony for its citizens. First, they disseminate the message to all levels of government and society using both formal and non-formal means of communication. As for the formal channels, it is done by the government itself through the flag raising ceremony at the Regional Work Units (SKPD) which is held on every Monday morning. In addition to the main message, the ceremony participants are also presented with spiritual nourishment or religious education for seven minutes. Among the materials of the message oare the harmony in diversity, no anarchy, maintaining security and order in their respective environments, creating conducive conditions, peace, maintaining harmony in the workplace. Likewise it is also done through both educational institutions and Islamic schools from early childhood level, to high school. At the flag ceremony, message associated with harmony and peace is given. Likewise, every Friday in activities of Qur'an reading, recitation of Surat Yasin, the recitation of most Beautiful God's names, tahlil and prayer together, so as to ensure the country and the nation to remain safe, orderly, peaceful, so as to carry out the development programs, as well as staying away from temptation, disasters, and plagues. In addition, through formal, non-formal waya, the message is also disseminated through the Friday sermon, lecture between maghrib and isha, after dawn prayer, during informal gatherings which have a network from city level up to RT / RW, among the Mosque youths, and Qur'an education centers, etc.

Based on the results of interviews with Nusyirwan ${ }^{24}$ Chairman of the Indonesian Ulema Council of Sungai Penuh City, the City indeed reflects a

${ }^{21}$ A. Zaki Badawi, Mu'jam Musthalahat al-'Ulum al ljtima'yat, (Beirut: Maktabah Lubnan, 1982), p. 426

${ }^{22}$ Departemen Pendidikan dan Kebudayaan, Kamus besar bahasa Indonesia,(Jakarta: Balai Pustaka, 2005), p.1204

${ }^{23}$ Yayah Khisbiyah, Menepis Prasangka, Memupuk Toleransi untuk Multikultural: Dukungan dari Psikologi Sosial,(Surakarta:PSB-PS UMS. 2007),p. 4

${ }^{24}$ Nusyirwan, Ketua MUI Kota SungaiPenuh, Interview, dated, 16 September 2016 
religious diversity, although the majority embrace Islam, between religious communities there has never been a conflict; the minority never felt oppressed by the majority. MUI always puts forward the attitude of tolerance between religious groups should not have suspicion of each other especially the majority and the minority. It should not be rigid on the opinions and beliefs of the others, viewing other as always wrong causing antipathy to the other people's belief. By maintaining such conditions, the relations between religions are always harmonious and peaceful, even among religious groups always working so well with the government, and the government also expects such inter-religious harmony, always promoting moderation, which is located at the middle position of the two conditions, namely: and shortage and excess. Moderate education is building the spirit moderation, or not the of extreme, radical, conservative, liberalist behavior. In this way, we can build a sense of togetherness, the feeling of closeness and love one another in unity with others. We also need to promote mutual respect for differences (to agree in disagreement), live side by side with one another, creating anti-hegemony and anti-domination.

In preventing the attitude of radicalism and conflict, the government has formed Forum for Community Early Vigilance (FKDM) which is a strategic element both for horizontal and vertical relations, which serves to create a conducive atmosphere, especially related to security issues and to invite the community to be more persuasive when discovering potential for violence and conflict and not to cause anxiety in the community. Religious groups should also be aware that religious and cultural diversity is inevitable, then they should be aware of religious and cultural diversity, as well as be able to apply inclusivity and diversity in the behavior of religious life, having a sense of moderation in defining the differences and behavioral diversity in society. Religious followers should avoid violent behavior, coercion which will cause the loss of tolerance. Indonesian society in general is composed of people of different ethnicity, race, creed, religion and political ideology. Likewise, Sungai Penuh City specifically, should share the responsibility to maintain harmonious relations between diverse communities. Diversity is a blessing for all, thereby creating harmony in diversity, will be a realization of peace in the life of the nation.

The Chairman of the Forum for Religious Harmony (FKUB) Sungai Penuh City, Ahmad Zuhdi ${ }^{25}$, in an interview said that there are various

${ }^{25}$ Ahmad Zuhdi, Head of FKUB Sungai Penuh City, Interview, in Sungai Penuh City, dated 19 September 2016 
religious groups here, Muslims, Protestants, Catholics, Hindus, Buddhists and Confucians. In this forum, all religions are represented as a member of the executive board. By agreement, all religious groups shall contribute to creating harmony and peace between them, one of which is through this forum that promotes moderation, tolerance, mutual trust, not interfering with each other and always put togetherness first. The Forum has also established the Council for Religious Deliberation which basically regulates cooperation between religious communities and seeks solution to inter-religious issues as well as supports the government in maintaining national integrity.

In addition, regarding the diversity of culture, race or ethnicity, the Sungai Penuh City has established the Nation's Assimilation Forum (FPK). Based on the interview with the Chairman of FKP, Masrur Lubis ${ }^{26}$, in Sungai Penuh City there are several ethnic groups, namely Kerinci, Jambi, Minang, Muslim Batak, Christian Batak, Java, Palembang, Malay, and Chinese. Meanwhile, based on observation, many other ethnic groups have not been integrated into this forum such as Aceh, Riau, Bengkulu, Banjar, etc. This forum has agreed to remain united to establish regular communication and keeping the unity with respect for differences, to always prioritize togetherness, thereby bringing harmony and peace into society. Even the Sungai Penuh City has become the safest city in the province of Jambi. When asked what is Indonesia? The answer would be it is a country whose people live on thousands of islands with various religious, ethnic, and language groups. They live with the spirit of building harmony and peace to achieve common prosperity, with the four pillars of nationality, namely "1945 Constitution, Pancasila, Bhinneka Tunggal Ika, and the Unitary State of the Republic of Indonesia".

The Mayor of Sungai Penuh, as the first person in charge of security, order and peace in the region, after taking several policies and establishing forums that deal directly with religion and culture, also personally always called on the entire people of Sungai Penuh to avoid radical actions, brawl, mischief, and that they should be able to implement the attitude of harmony, and observe the tolerance values in everyday life. This appeal is delivered on Sungai Penuh City Regional Radio periodically. He also extended such call on each anniversary of Islamic holidays, safari Ramadhan, Ied al-Fitr, Ied alAdha and on other occasions, thereby creating security and order and

${ }^{26}$ Masrur Lubis, Head of FPK, Sungai Penuh City, Interview, in Sungai Penuh City, dated 23 September 2016 
harmony. Communities can accept a deviation from what is believed or practiced despite the differences.

Efforts to promote harmony in diversity is carried out through educational institutions as Marwan ${ }^{27}$ a supervisor at the Ministry of Religious Affairs of Sungai Penuh said that based on the Regulation of the Minister of Education and Culture Number 69 / 2013 concerning the Basic Framework and Curriculum Structure of High School/Madrasah Aliyah, basic competence of religious and moral education, there is one subject that teaches students to appreciate and practice caring nature (mutual aid, cooperation, tolerance, peace) and to maintain harmony. Then the supervisor also stressed that teachers of religious education in schools and madrasah can internalize these values to the maximum, so that all students can implement in the school environment, family and society.

As reported by one of the teachers of Religious Education, Aflizar, ${ }^{28}$ based on the Regulation of the Minister of Education and Culture No. 82 / 2015 the violence in the field of education should not happen, and the school should be a safe and comfortable zone for learners. There should be no violence committed by educators, if committed they shall be punished. However, we as teachers also need protection in teaching, because currently many teachers have been reported to police by parents because taking minor disciplinary actions against students, while the teacher has the right to educate children including disciplining students with sanctions. In addition, efforts have continued to build harmony in diversity because our students come from a variety of ethnic and tribal as well as religious backgrounds. We have been doing a school culture in the form of smiles, greetings, politeness and courteous manners, smiling are required when they run into each other, regardless of religion, ethnicity and descent. Thus the higher their tolerance, fellow students will find friendship, the friendship between them will be more closely.

Based on the results of interviews with one of the community leaders, M. Nawir, ${ }^{29}$ the community of Sungai Penuh City has always been very heterogeneous and multi-cultural from various regions in Indonesia, but their arrival has received a positive response from the natives. They really appreciate and respect the presence of migrants from outside the area with a variety of tribes, ethnicities. Even neighbors can be friends. Some of them intermarried

${ }^{27}$ Marwan, Supervisor at Ministry of Religious Affairs Sungai Penuh City, Interview, 7 October 2016 tober 2016

${ }^{28}$ Aflizar, Religious Education teacher, SMAN Sungai Penuh City, Interview, 10 Oc-

${ }^{29}$ M. Nawir, Community Leader Sungai Penuh City, Interview, dated, 4 November 2016 
and have children. They already feel that life must be harmonious to share diversity, and this is a necessity that must be nurtured, cared for, built to form a force in reaching goals.

Similarly, the results of interviews with the Indigenous Leader of Sungai Penuh City, M. Sudin ${ }^{30}$ revealed that in carrying out marriage to indigenous people, they do not prohibit the use of each other's culture; in fact they are free to use the traditional clothes, for example the marriage between Kerinci with Minang tribes, the traditional clothes Kerinci and Minang are used interchangeably so that both parties feel equally pleased. Thus the sustainability of each culture can be well preserved. This is also in line with the results of the field observations conducted at an intermarriage party, which at certain time, the bride and groom changed traditional clothes. With this mixed marriage, the whole family looks happy with diversity harmony, peace, friendship, cooperation, and mutual respect between them. This fact is suppurted by the argument proposed by Zaenuddin Hudi Prasojo (2015) that local culture is an important element in the efforts of building harmony in the multicultural society of Indonesia. Customary law as apart of local genious elements is in the positition to be empowered to support the efforts of building peace and harmony.

If harmony is already established, it will create peace, justice will be realized, the country will be free of conflicts, disputes, and chaos. Only in this way can the government together with the community be able to carry out development in all fields. Likewise, at the national level several accomplishments have been made such as the Satya Lancana Pembangunan (development award) from the President, the Wahana Tata Nugraha (transportation award) from the Ministry of Transportation, received Unqualified Opinion in terms of financial management from the Supreme Audit Agency, won a certificate and trophy of Adipura for Clean City 2015, Caring and Environmentally Aware school from the Ministry of Education and Culture and the Ministry of Environment and Forestry. It is expected that the target of becoming an economically independent city in 2016 can be achieved. Therefore, Sungai Penuh City, which is part of the Indonesian nation, has participated in building the nation, strengthening the Unitary State of the Republic of Indonesia based on Pancasila and the 1945 Constitution in order to achieve a just, safe, and prosperous country.

${ }^{30}$ M. Sudin Customary Leader of Sungai Penuh City, Interview, dated 11 November 2016 


\section{CONCLUSION}

Humans are created in religious and cultural diversity, not uniformity. Diversity is the Devine law, Divine grace to be grateful for, the law of the times, something that is commonplace, a must, a nation integrity, which must be accepted as a positive reality and does not need to be deplored, and be used as a force that should be maintained for unity of the nation. Diversity is a form of God's abundant mercy to humans, and we should be able to share such diversity, in addition to religious diversity which is a blessing for all and cultural diversity is a grace of God the creator.

Sungai Penuh City Government has successfully built harmony in religious and cultural diversity, which is done through formal channels which are implemented in a hierarchical manner, and non-formal through religious organizations. In general, the government and society have achieved a seamless harmony in diversity to create peace, compassion, caring, civility, tranquility and security. The society has also responded positively and implement it in daily life. Sungai Penuh City thus has been able to carry out the development programs evenly and equitably. It can be proved with a lot of awards and certificates for its success in development, as well as the accomplishments that were achieved at the provincial and national levels, so that the target of Sungai Penuh to become an economically independent city in 2016 can be achieved.

Recognition of religious and cultural diversity in our society is beginning to fade as each religious and cultural group thinks that it is only group that is right, so suspicion between religious and cultural groups has begun to emerge which trigger the concepts of Islamic and Christian state. This is a threat to the national integration. Every religion and culture should be able to re-evaluate the negative attitude toward religious and cultural diversity, which lead to a wider conflict if not managed. It, should be able to create harmony and peace in the society. Therefore, the efforts in building harmony should continue to be developed, civilized, socialized, and conditioned in daily life of the community, so that the atmosphere would be safe and orderly, equitable development can be implemented, and people will have a better and happier life. 


\section{REFERENSI}

Abdullah, M.A. (2000). Dinamika Islam Kultural Pemetaan Atas Wacana Keislaman Kontemporer, Bandung: Mizan.

Ali, M. (2003). Teologi Pluralisme-Multikultural: Menghargai Kemajemukan Menjalis Kebersamaan, Jakarta: Buku Kompas.

Azra, A. (2003). Pengantar dalam Dede Rosyada, Pendidikan Kewargaan (Civic Education): Demokrasi, Hak Asasi Manusia \& Masyarakat Madani, Jakarta: ICCE UIN Syarif Hidayatullah.

--------, (2005). Syariat Islam dalam Bingkai Nation State, Islam Negara \& Civil Society, Gerakan dan Pemikiran Islam Kontemporer, Jakarta: Paramadina.

Badawi, Z. (1986). Mu'jam Musthalahat al-Ulum al-Ijtima'yat, Beirut: Maktubah Lubnan.

Casram, C. (2016). Membangun Sikap Toleransi Beragama dalam Masyarakat Plural. Wawasan: Jurnal Ilmiah Agama Dan Sosial Budaya, 1(2), 187198. doi:http://dx.doi.org/10.15575/jw.v1i2.588.

Daya, B. \& Beck, H.L. (Eds.) (1992). Ilmu Perbandingan Agama di Indonesia dan Belanda, Jakarta: INIS.

Hidayat, K. \& A.F.A.G (eds.) (2005). Islam Negara \& Civil Sosiati, Gerakan dan Pemikiran Islam Kontemporer, Jakarta: Paramadina.

Hidayat \& Nafis, M. W. (1995). Agama Masa Depan, Perspektif Filsafat Perinial, Jakarta: Paramadina.

Khisbiyah, Y. ( 2007). Menepis Prasangka, Memupuk Toleransi untuk Multikultural: Dukungan dan Psikologi Sosial, Surabaya: PSB-PS UMS.

Komari, A.A (1995). Perang dan Damai dalam Islam, Bandung: Pustaka Setia.

Majalah Kota Sungai Penuh (2015). Sehalun Suhak Selatuh Bedil Warta Kota, Sungai Penuh: Humas dan Protokol Setda.

Madjid, N. (1997). Tradisi Islam Peran dan Fungsinya dalam Pembangunan di Indonesia, Jakarta: Paramadina.

Mawardi, A.H.B. (2002). Etika Agama dan Dunia Memahami Hakikat Beragama dan Berinteraksi di Dunia, Bandung: Pustaka Setia (translation into Indonesian).

Muhit, H. (at.al). (2008). Sarung \& Demokrasi dari NU untuk Peradaban Keindonesiaan, Surabaya: Khalista. 
Munawar, A.W. (1994). Kamus Al Munawar, Yokyakarta: PP Krapyak.

Prasojo, Z.H. (2015). INDIGENOUS COMMUNITY, CUSTOMARY LAW AND MULTICULTURALISME IN INDONESIA. Al-Albab, 2(1). doi:http://dx.doi.org/10.24260/alalbab.v2i1.26

-, (2016). Social Change and the Contributions of the Tionghoa, Dayak and Melayu (Tidayu) in West Kalimantan. In Victor T. King, Zawawi Ibrahim \&Noor Hasharina Hassan (Eds.). Borneo Studies in History, Society and Culture. Singapore: Springer. P: 427-442.

Rahman, B.M. (2001). Islam dan Pluralis Kesetaraan Kaum Beriman, Jakarta: Paramadina.

Rosyada, D. (2003). Demokrasi dan Hak Asasi manusia \& Masyarakat Madani, Jakarta: LkiS.

Susanto, T. (2007). Melampaui Toleransi: Merenung Bersama Walzer dalam Ihsan Ali- Fauzi, dkk. Demi Toleransi Demi Pluralisme, Jakarta: Paramadina.

Setiawan, M.N. (2012). Pribumisasi Al-Quran: Tafsir Berwawasan Keindonesiaan, Yokyakarta: Kankaba.

Syam, N. (2011). Mazhab-Mazhab Antropologi, Yokyakarta: LkiS.

Taufik, M.T. (2012). Etika Komunikasi Islam, Bandung: Pustaka Setia.

Ulwan, A.N. (1993). Pedoman Pendidikan Anak dalam Islam, Semarang: Asysyifa' (translation into Indonesian).

Widjaja, H.A.W. (2002). Pedoman Pelaksanaan Pendidikan Pancasila pada Perguruan Tinggi, Jakarta: Raja Grafindo Persada.

Yusuf, Y. (2004). Prasangka Beragama, Jakarta: Penamadani. 